\title{
Quantitative and Temporal Definition of the Mla Transcriptional Regulon During Barley-Powdery Mildew Interactions
}

\author{
Matthew J. Moscou,, ${ }^{1,2}$ Nick Lauter, ${ }^{2,3}$ Rico A. Caldo, ${ }^{2}$ Dan Nettleton, ${ }^{1,4}$ and Roger P. Wise ${ }^{1,2,3}$ \\ ${ }^{1}$ Interdepartmental Program in Bioinformatics and Computational Biology, and ${ }^{2}$ Department of Plant Pathology, lowa State \\ University, Ames, IA 50011-1020, U.S.A.; ${ }^{3}$ Corn Insects and Crop Genetics Research Unit, USDA-ARS, Ames, IA 50011-1020, \\ U.S.A.; ${ }^{4}$ Department of Statistics, lowa State University, Ames, IA 50011-1210, U.S.A.
}

Submitted 16 September 2010. Accepted 6 February 2011.

Barley Mildew resistance locus a (Mla) is a major determinant of immunity to the powdery mildew pathogen, Blumeria graminis f. sp. hordei. Alleles of Mla encode cytoplasmic- and membrane-localized coiled-coil, nucleotide binding site, leucine-rich repeat proteins that mediate resistance when complementary avirulence effectors $\left(A V R_{a}\right)$ are present in the pathogen. Presence of an appropriate $A V R_{a}$ protein triggers nuclear relocalization of MLA, in which MLA binds repressing host transcription factors. Timecourse expression profiles of plants harboring Mla1, Mla6, and Mla12 wild-type alleles versus paired loss-of-function mutants were compared to discover conserved transcriptional targets of MLA and downstream signaling cascades. Pathogen-dependent gene expression was equivalent or stronger in susceptible plants at $20 \mathrm{~h}$ after inoculation (HAI) and was attenuated at later timepoints, whereas resistant plants exhibited a time-dependent strengthening of the transcriptional response, increasing in both fold change and the number of genes differentially expressed. Deregulation at $20 \mathrm{HAI}$ implicated $16 \mathrm{HAI}$ as a crucial point in determining the future trajectory of this interaction and was interrogated by quantitative analysis. In total, 28 potential transcriptional targets of the MLA regulon were identified. These candidate targets possess a diverse set of predicted functions, suggesting that multiple pathways are required to mediate the hypersensitive reaction.

The obligate fungal biotroph, Blumeria graminis f. sp. hor$d e i$, is the causal agent of powdery mildew on barley (Hordeum vulgare L.) (Bushnell 2002). The genetics and physiology of

GeneChip data is available in ArrayExpress database under accession numbers E-TABM-82 (BB2 Sultan-5 experiment) and E-TABM-142 (BB10 Manchuria experiment).

Current address for M. J. Moscou; The Sainsbury Laboratory, John Innes Centre, Colney Lane, Norwich NR4 7UH, U.K.

Current address for R. A. Caldo; Monsanto Company, 800 North Lindbergh, Creve Coeur, MO 63167, U.S.A.

Corresponding author: R. P. Wise; E-mail: rpwise@iastate.edu

* The $\boldsymbol{e}$-Xtra logo stands for "electronic extra" and indicates that one supplementary figure and two supplementary tables are published online.

This article is in the public domain and not copyrightable. It may be freely reprinted with customary crediting of the source. The American Phytopathological Society, 2011. this host-pathogen interaction have been well characterized, beginning with a report by Biffen (1907). Recognition of $B$. graminis f. sp. hordei is mediated by several loci distributed throughout the barley genome and designated $M l$ (Mildew resistance locus) (Jørgensen 1994). Most well-known is Mla, located on the short arm of chromosome $1 \mathrm{H}$, with approximately 30 alleles that mediate resistance when corresponding $A V R_{a}$ effectors are present in the pathogen (Jørgensen 1994). In contrast to the genetic structure of Mla with multiple alleles at a single locus, $A V R_{a}$ genes are scattered throughout the $B$. graminis f. sp. hordei genome, with the cloned $A V R_{a 10}$ belonging to a diverse family encoding proteins that lack secretion signals (Ridout et al. 2006; Skamnioti et al. 2008). Sequenced alleles of Mla encode cytoplasmic- and membrane-localized coiled-coil (CC), nucleotide binding site, leucine-rich repeat proteins (Halterman and Wise 2004; Seeholzer et al. 2010; Shen et al. 2003) that translocate into the nucleus after recognition of a corresponding $\mathrm{AVR}_{\mathrm{a}}$ effector from $B$. graminis $\mathrm{f}$. sp. hordei. Nuclear localization of $\mathrm{AVR}_{\mathrm{a}}$ is required to mediate the hypersensitive reaction (HR) (Shen et al. 2007), which may be dependent on the direct interaction between appropriate MLA and $\mathrm{AVR}_{\mathrm{a}}$ proteins (Seeholzer et al. 2010). After recognition, the CC domain of MLA binds the transcription factors WRKY1 and WRKY2 (WRKY1/2) (Shen et al. 2007). Thus, the translocation of MLA and subsequent interaction with WRKY $1 / 2$ is expected to remodel the transcriptional landscape leading to the HR.

The physical association of MLA with transcription factors indicates that activation, inhibition, or modulation of gene expression may be required to mediate the HR in epidermal cells breached by fungal appressoria. In this mRNA-based model for induction of the HR, the identification of the primary downstream transcriptional targets of MLA would make it possible to address several central questions, such as what are the genes and pathways that initiate the HR and which molecular processes are involved in mediating this cell death program. While investigations conducted prior to knowledge of MLA localization were able to link the kinetics of several well-known pathogenesis-related $(P R)$ and other genes with the development of $B$. graminis f. sp. hordei on the host, they were limited in their ability to causally associate the regulation of gene expression to Mla-meditated resistance (Collinge et al. 2002; Eichmann et al. 2006; Gjetting et al. 2007).

Previously, we investigated the reprogramming of the barley transcriptome in response to powdery mildew infection by utilizing three near-isogenic lines of barley (harboring different alleles of Mla) and two contrasting isolates of B. graminis $\mathrm{f}$. 
sp. hordei (Caldo et al. 2004). Our primary objective at that time was to identify conserved genes whose expression patterns differed across incompatible (i.e., Mla6-AVR $a 6$, Mla13$A V R_{a 13}$ ) versus compatible (i.e., Mla6-AVR $R_{a 13}$, Mla13-AVR $R_{a 6}$ ) interactions. A total of 22 host genes were identified at a threshold $P$ value $<0.0001$ and false discovery rate (FDR) of $7 \%$, for which increased expression was observed from 0 to $16 \mathrm{~h}$ after inoculation (HAI) in all interactions relative to the $0 \mathrm{HAI}$ timepoint (Caldo et al. 2004). From 20 to $32 \mathrm{HAI}$, these genes displayed divergent expression between incompatible and compatible interactions, with greater expression almost always in the incompatible interaction (Caldo et al. 2004). In a subsequent experiment, relaxation of the stringency paired with correlation to the original pattern extended this list to an additional 134 genes $(P<0.01)$ (Caldo et al. 2006). Functional analysis of three of these genes (chorismate synthase, anthranilate synthase $\alpha$ subunit 2, and chorismate mutase 1) demonstrated that they were necessary for penetration resistance against $B$. graminis f. sp. hordei (Hu et al. 2009). In contrast, another gene, Blufensinl $(B \ln 1)$, encoding a small peptide induced by a broad range of fungal pathogens, was shown to negatively impact defense (Meng et al. 2009). Neither silencing nor overexpression of these four genes suppressed the HR mediated by MLA, suggesting their roles are sufficiently downstream of MLA signaling such that they do not compromise the HR (Bent and Mackey 2007).

Here, we describe an alternative approach that takes advantage of paired wild-type and loss-of-function mutant alleles of Mla. Initially, we establish a comprehensive index of temporal gene expression patterns after inoculation with $B$. graminis $\mathrm{f}$. sp. hordei. Interestingly, the overall transcriptional response was equivalent or stronger at $20 \mathrm{HAI}$ in compatible interactions; however, this response was not quantitatively sustained over time as compared with incompatible interactions. By identifying the conserved quantitative differences between three wild-type and mutant pairings at $16 \mathrm{HAI}$, we predict a set of candidate genes that are hypothesized to be transcriptional targets of the MLA-mediated HR.

\section{RESULTS}

\section{Concept and experimental design.}

Our early experiments focused on distinguishing the transcriptional differences between incompatible and compatible interactions using alleles of Mla and complementary isolates of B. graminis f. sp. hordei (Caldo et al. 2004). Specifically, we used a matrix of three near-isogenic barley lines with introgressed Mla1, Mla6, or Mla13 alleles, each challenged with the contrasting powdery mildew isolates 5874 (containing $A V R_{a 1}$ and $A V R_{a 6}$ ) and $\mathrm{K} 1$ (containing $A V R_{a 1}$ and $A V R_{a 13}$ ) (Caldo et al. 2004, 2006). Since there were no noninoculated tissues in this experiment, we were restricted to evaluating divergent responses between different $M l a-A V R_{a}$ pairings.

Here, we included noninoculated tissue to generate a comprehensive index of differential steady-state expression levels in response to powdery mildew infection, used a single isolate of $B$. graminis f. sp. hordei, and incorporated several loss-offunction mutants of Mla (Fig. 1). The use of three incompatible $\left(M l a-A V R_{a}\right)$ versus compatible $\left(m l a-A V R_{a}\right)$ pairings leveraged the diversity inherent in this host-pathogen interaction. These combinations represent fast versus intermediate resistance-gene kinetics (i.e., Mlal and Mla6, pathogen ingress halted at haustorial development, in contrast to Mla12, which allows limited hyphal growth), Rarl-dependent (Mla6 and Mla12) versus Rarl-independent (Mlal), and Manchuria (Mlal and Mla6) versus Sultan-5 (Mla12) genetic backgrounds (Boyd et al. 1995; Meng et al. 2009; Shen et al. 2003; Torp and
Jørgensen 1986; Wise and Ellingboe 1983; Zhou et al. 2001). Utilizing these reagents, we set out to predict conserved transcriptional targets of MLA that mediate the HR upon its translocation into the nucleus (Shen et al. 2007).

As illustrated in Figure 1, our experimental material consisted of three barley lines carrying the resistance alleles Mlal (CI 16137), Mla6 (CI 16151), and Mla12 (Sultan-5) and their corresponding loss-of-function mutants, mlal-m508, mla6$m 9472$, and mla12-m66, respectively (Meng et al. 2009; Moseman 1972; Torp and Jørgensen 1986; Shen et al. 2003; Zhou et al. 2001). A split-split-plot design with three independent biological replications was used to obtain expression measurements (Kuehl 2000). Genotype was the whole-plot treatment factor, and each whole-plot experimental unit consisted of a pair of trays of the same genotype (one inoculated and one noninoculated) side-by-side in a growth chamber during the timecourse after inoculation. The split-plot experimental units were the individual trays that were randomly assigned to inoculation with $B$. graminis f. sp. hordei $5874\left(A V R_{a l}\right.$,

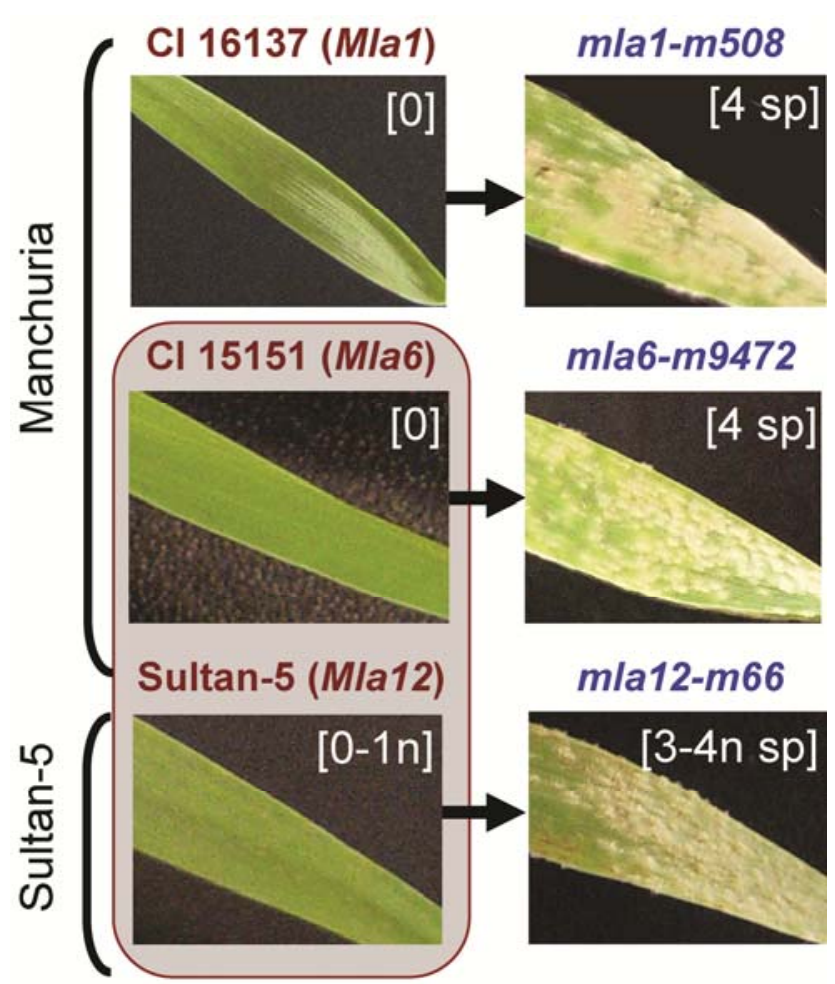

Fig. 1. Seedling phenotypes and experimental design. Transcript profiling was based on a split-split-plot design with replications as blocks, genotype as the whole plot factor, inoculation treatment as the split-plot factor, and time as the split-split-plot factor. Seven-day-old seedlings of wild-type Mla1 (CI 16137), Mla6 (CI 16151), Mla12 (Sultan-5), and their corresponding loss-of-function mutants, mla1-m508, mla6-m9472, and mla12$m 66$, respectively, were inoculated with Blumeria graminis f. sp. hordei isolate $5874\left(A V R_{a 1}, A V R_{a 6}\right.$, and $\left.A V R_{a 12}\right)$ or noninoculated. Fifteen first leaves were harvested at $0,8,16,20,24$, and $32 \mathrm{~h}$ after inoculation (HAI). One Barley1 GeneChip was used for each of the 216 split-split-plot experiment units, corresponding to six genotypes $\times$ two inoculation treatments $\times$ six timepoints $\times$ three replications. Wild-type derived mutant seedling infection types are shown 7 days after inoculation. Lines containing Mlal and Mla6 are introgressed into Manchuria background, whereas Mla12 and its mutant are derived from Sultan-5. Cells labeled in red (wild type) and blue (mutant) are incompatible and compatible, respectively, when inoculated with $B$. graminis f. sp. hordei 5874. Gray highlight indicates Rar1-dependant genotypes. An infection type of 0 to 2 is considered to be resistant ("-" designates incompatible or no sporulation), whereas an infection type of 3 to 4 is considered to be susceptible ("+" designates compatible or abundant sporulation). $0=$ immune; $0-1 \mathrm{n}=$ few to several small necrotic flecks $(0.5 \mathrm{~mm}) ; 4 \mathrm{sp}=$ completely susceptible 
$A V R_{a 6}$, and $\left.A V R_{a 12}\right)$ or to noninoculated control. The split-splitplot experimental units were rows of plants within trays randomly assigned to the harvest times $0,8,16,20,24$, and 32 HAI. The analysis we present here is based on gene expression data from six genotypes $\times$ six timepoints $\times$ two inoculation treatments $\times$ three replications, collected using 216 Barley1 GeneChips (Close et al. 2004).

\section{Defining the set of barley genes responsive to B. graminis f. sp. hordei inoculation.}

Fold-change estimates and associated $P$ values for differential expression between inoculated and noninoculated treatments for each timepoint were determined using a mixed linear model. The model included fixed effects for genotype, treatment $(B$. graminis f. sp. hordei 5874 or noninoculated), timepoint, and all interactions among these factors, as well as random effects for replication and the corresponding interactions of genotype $\times$ replication (whole-plot), genotype $\times$ treatment $\times$ replication (split-plot), and genotype $\times$ time $\times$ replication (split-split-plot) (Kuehl 2000; Wolfinger et al. 2001). FDR were estimated using the histogram-based technique as described by Nettleton and associates (2006). In summary, controlling the FDR at $0.0001,0.01$, and $1 \%$ found $3,810,6,846$, and 15,149 genes differentially expressed between inoculated and noninoculated plants for at least one timepoint among the wild-type genotypes, respectively. The large number of genes identified as differentially expressed is a result of strong statistical power, the examination of multiple timepoints, and most significantly, the strong transcriptional response of barley to powdery mildew infection. To avoid loss of information by selecting an arbitrary FDR cutoff, we incorporated all three FDR cutoffs for subsequent analyses.

\section{A total of 54 timecourse patterns of expression define the transcriptional response of barley to $B$. graminis f. sp. hordei infection.}

We identified composite patterns separately for both incompatible and compatible interactions, based on conserved differential gene expression within the sets of wild-type Mla and derived mutant lines, respectively. Each timepoint was evaluated for differential expression between inoculated and noninoculated treatments using a voting approach that considered all three genotypes at each of the three FDR levels, for a total of nine comparisons. A consensus designation of induced (+) or suppressed (-) was recorded only when the differential expression was present in at least four of the nine comparisons (discussed below). Based on the selected FDR, the directions of any significant changes (+ or - ) were always the same within a gene and timepoint so that the consensus designation of + or represents the direction of change common to all significant differences within a gene for a given timepoint. If the gene was not differentially expressed based on four of nine criterion, it was given a 0 . As illustrated in Figure 2, ternary representations of these consensus designations were used to graphically depict the composite patterns of 3,876 genes. For example, a gene upregulated at the 20 and 24 HAI timepoints would be represented as $000++0$. Conversely, if the same gene was downregulated only at those two timepoints, the representation would be $000-0$. This approach has the advantage of removing genotype-specific expression and leverages several FDR to identify conserved sets of genes that have particular differential expression responses to inoculation with the 5874 isolate $\left(A V R_{a 1}, A V R_{a 6}, A V R_{a 12}\right)$ of $B$. graminis f. sp. hordei.

Composite patterns for incompatible and compatible interactions were grouped into three main categories, based on the timing of differential expression, early (0 to $16 \mathrm{HAI})$, late (20 to $32 \mathrm{HAI}$ ), or a mixture of these responses (Fig. 2; Supple- mentary Table S1). Upregulation predominates both the early and mixed responses to challenge with powdery mildew in both incompatible (650 genes) and compatible (515 genes) interactions. In contrast, genes that are downregulated were poorly represented in early and mixed-response categories, with 93 and 90 genes in incompatible and compatible interactions, respectively. More genes were downregulated in late responses, with 832 and 981 upregulated and 1,511 and 1,624 genes downregulated among wild-type and mutant lines, respectively. In general, incompatible and compatible interactions had similar representation of patterns, which resulted from the selection of early timepoints in the interaction of barley and powdery mildew, before the onset of massive fungal growth.

Of the 54 composite patterns observed, 52 contain only combinations of two designations, i.e., '+' with 0 or '-' with 0 (Fig. 2), indicating that trends of induction or suppression do not reverse within this timecourse. Not shown in Figure 2 are the two composite patterns that are mixtures of both induction and suppression across the timecourse. However, each of these is represented only by a single gene, which suggests that these patterns may be exceptions to the apparent rule that the direction of differential expression does not reverse. If these are indeed exceptions, one might expect the representative genes to lack clear roles in disease defense. This may be the case, since Barley1_11076 (incompatible: +000-0; compatible: +00-0) is predicted to be a $\mathrm{Ca}^{2+}$-dependent nuclease, while Barley1_ 50237 (incompatible: +00000; compatible: +000-0) has sequence similarity to the defective embryo and meristems gene in tomato (Keddie et al. 1998).

\section{Relation of composite patterns to infection kinetics.}

Several characteristics distinguish incompatible and compatible responses. First, there are almost twice as many genes upregulated in incompatible (153 genes) versus compatible (84 genes) interactions in early response patterns (Fig. 2). Second, the most represented patterns in incompatible interactions were $00000+$ (323 genes) and 00000- (832 genes) for late responses, while these same two classes are considerably reduced (147 and 326 genes, respectively) in compatible interactions. Accompanying this reduction is an increase in four of the remaining six late response patterns $(0000++, 000+00$, $0000+0,000++0)$ for compatible as compared with incompatible interactions. The effect was exactly mirrored with the downregulated patterns, indicating that late response gene expression was occurring even later in incompatible interactions regardless of its direction (Fig. 2). The late responses at the 24 and 32 HAI timepoints are both after penetration of epidermal cells by $B$. graminis f. sp. hordei and the formation of haustoria. Thus, susceptible plants were responding earlier than their resistant counterparts, and this transcriptional outcome coincides with the physical interaction at the perihaustorial interface between plant cell and fungal pathogen.

\section{Integration of fold change into timecourse patterns of expression reveals an earlier response in compatible interactions.}

In order to understand the magnitude of the response to powdery mildew invasion, we integrated fold change as a measure of the quantitative effect occurring at each timepoint in inoculated versus noninoculated seedlings. We used only those genes with consensus patterns in either the wild-type or mutant genotypes, or both, and selected fold change ranges of 2 to 3,3 to 4,4 to 5, 5 to 10 , and greater than 10 , to broadly categorize induction or suppression of transcript accumulation at each timepoint. As induction or suppression is consistent, fold change refers to inoculated versus noninoculated for induced genes, and conversely, noninoculated versus inoculated for suppressed genes. 


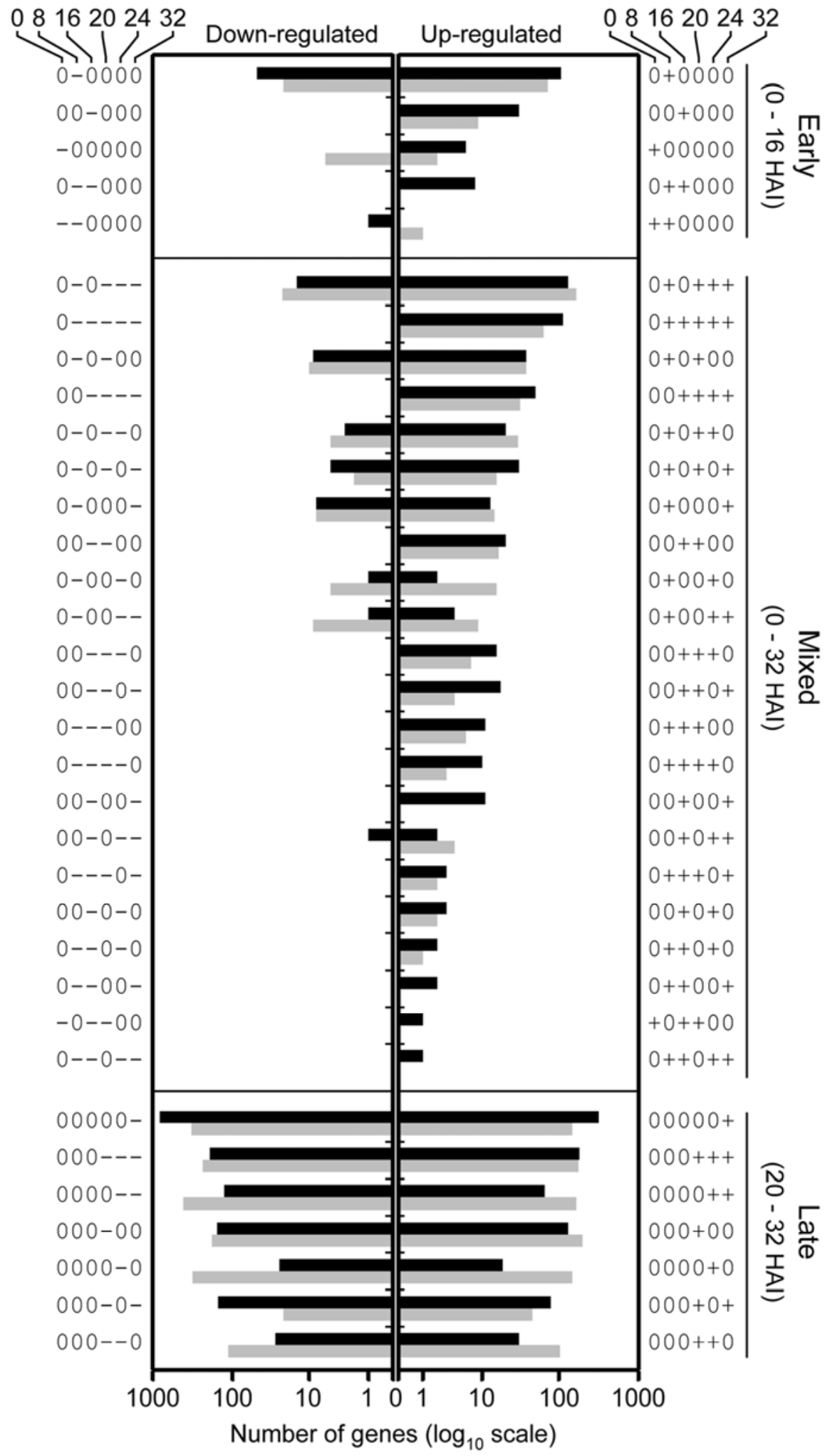

Fig. 2. Distribution of consensus expression patterns in incompatible and compatible interactions. Patterns represent a consensus of differential expression in at least four of nine genotype $\times$ false discovery rate comparisons, with induced or suppressed gene expression in inoculated plants relative to noninoculated plants for a given timepoint, represented by either a ' + ' or '-', respectively. If the gene is not differentially expressed based on the consensus, it is given a ' 0 '. Concatenation of all six timepoints $(0,8,16,20,24$, and $32 \mathrm{~h}$ after inoculation [HAI]) provides the patterns shown on the borders. The number of genes with consensus patterns in incompatible $\left(M l a-A V R_{a}\right)$ or compatible $\left(m l a-A V R_{a}\right)$ interactions are illustrated by black and gray horizontal bars, respectively. The horizontal axis is $\log _{10}$-scale. Patterns were ordered based on the total number of genes from incompatible and compatible interactions within each response category (early [0 to $16 \mathrm{HAI}$, mixed, and late [20 to $32 \mathrm{HAI}$ ). 
As illustrated in Figure 3 (an alternate presentation is shown in Supplementary Figure S1), both incompatible and compatible interactions exhibited a several-fold increase in differentially expressed genes by $8 \mathrm{HAI}$, indicating that a substantial nonspecific response occurs regardless of the presence or absence of MLA. By $20 \mathrm{HAI}$, two major patterns in differential expression distinguish the two interaction types. Incompatible interactions revealed an ever-increasing set of genes that are both differentially expressed and intensifying in their relative fold change between 20 and 32 HAI. In contrast, compatible interactions show an early induction of gene expression with a high fold change at $20 \mathrm{HAI}$, but this effect either weakens gradually with time (mlal-m508) or the larger fold change categories (5 to 10 and >10) stabilize (mla6-m9472 and mla12m66).

It is unexpected that loss-of-function mla mutants would exhibit earlier induction or suppression of gene expression in response to inoculation. Early activation may represent a miscoordination in transcriptome reprogramming, in which the plant is initiating several pathways in an inappropriate order, thus providing a window of opportunity for the pathogen.
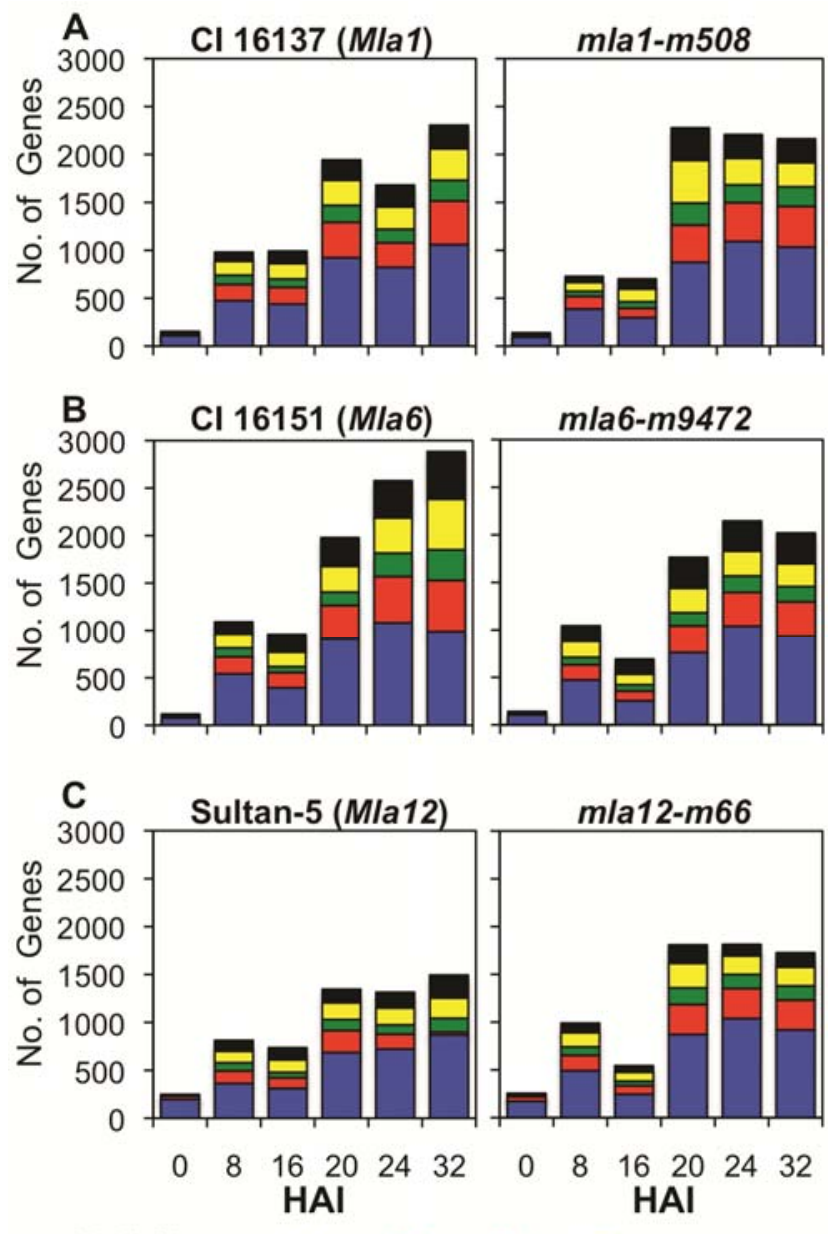

Fold Change: $\square$ 2-3 $\square$ 3-4 $\square$ 4-5 $\square$ 5-10 $\square>10$

Fig. 3. A stronger transcriptional response occurs at $20 \mathrm{~h}$ after inoculation (HAI) in loss-of-function mla as compared with wild-type plants. Fold change between inoculated and noninoculated plants was derived for genes with a consensus expression pattern, as shown in Figure 2, at each timepoint. Probe sets not meeting the fold-change cutoff of 2 at any timepoint were not included in this figure. Bar plots show the numbers of genes in fold-change categories of 2 to 3 (blue), 3 to 4 (red), 4 to 5 (green), 5 to 10 (yellow), and >10 (black) for barley lines containing wildtype and respective mutant alleles A, Mla1, mla1-m508; B, Mla6, mla6m9472; and C, Mla12, mla12-m66.
Alternatively, in the absence of MLA, B. graminis f. sp. hordei may activate these genes deliberately as a means of disarming the plant. Regardless of the mechanism, the transcriptional cascades observed at $20 \mathrm{HAI}$ implicate the time between 16 and $20 \mathrm{HAI}$ as a key turning point in reprogramming the defense transcriptome.

\section{Identification of the MLA transcriptional regulon.}

The in vitro interaction of the CC domain of MLA with the WRKY1/2 transcription factors, coupled with the observation of in planta physical association in the nucleus using Förster resonance energy transfer corroborates MLA as an interactor with WRKY1/2 (Shen et al. 2007). Both transcription factors are repressors of basal defense in compatible interactions with $B$. graminis f. sp. hordei, suggesting that the inhibitory function

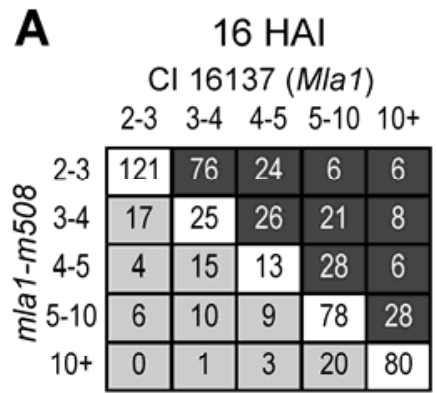

Cl 16151 (Mla6)

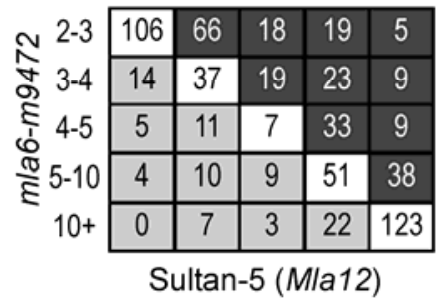

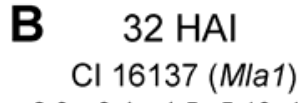

2-3 $\quad 3-4 \quad 4-5 \quad 5-10 \quad 10+$

\begin{tabular}{|c|c|c|c|c|}
\hline 549 & 202 & 45 & 17 & 5 \\
\hline 129 & 144 & 82 & 49 & 4 \\
\hline 29 & 61 & 45 & 68 & 5 \\
\hline 18 & 19 & 38 & 143 & 41 \\
\hline 0 & 4 & 4 & 49 & 190 \\
\hline
\end{tabular}

Cl 16151 (Mla6)

\begin{tabular}{|c|c|c|c|c|}
\hline 310 & 254 & 117 & 150 & 41 \\
\hline 41 & 79 & 72 & 129 & 49 \\
\hline 12 & 26 & 30 & 61 & 34 \\
\hline 4 & 12 & 30 & 94 & 103 \\
\hline 2 & 5 & 7 & 43 & 264 \\
\hline \multicolumn{5}{|c}{ ultan-5 (Mla12) }
\end{tabular}

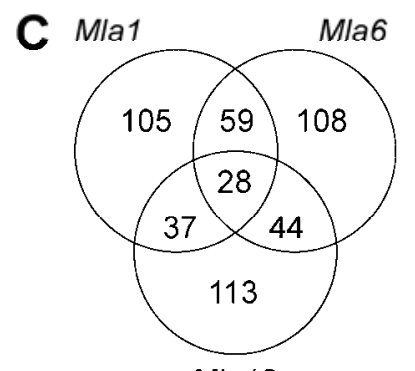

Mla12
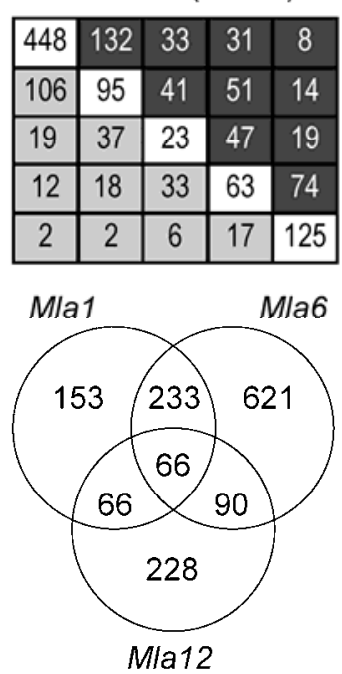

Fig. 4. Quantitative suppression of gene regulation correlates with resistance at both 16 and $32 \mathrm{~h}$ after inoculation (HAI). Intersection of genes between wild-type and mutant pairings for all fold change categories at $\mathbf{A}$, 16 and $\mathbf{B}, 32$ HAI. The upper right portion (dark gray) of individual matrices correspond to genes with suppressed expression in mutant as compared with wild-type alleles of Mla, whereas the lower left portion (light gray) of individual matrices correspond to genes having enhanced expression in mutant compared with wild-type alleles of Mla. C, Venn diagrams illustrating conserved genes at the intersections of the three wild-type versus mutant pairs, for 16 (left) and 32 (right) HAI. Numbers correspond to quantitatively suppressed genes displayed in the upper right portion (dark gray) of panels $\mathrm{A}$ and $\mathrm{B}$. 
of MLA provides gain-of-function expression of WRKY1/2 repressed targets. Though it is unclear if these two transcription factors are the only targets of MLA and whether or not the nature of WRKY1/2 transcriptional regulation after interaction with MLA is completely inhibitory, our paired analysis of wild-type and mutant lines provides a comprehensive template for identifying candidate genes that belong to the MLA transcriptional regulon.

We focused on $16 \mathrm{HAI}$, as it coincides with establishment of the perihaustorial interface between host epidermal cells and $B$. graminis $\mathrm{f}$. sp. hordei haustoria, nuclear relocalization of MLA, and the major transcriptional cascades observed at 20 HAI. Hence, it represents an ideal timepoint for detecting primary transcriptional targets of MLA and its interactors. We hypothesized that genes in the MLA transcriptional regulon would have quantitative effects between incompatible and compatible interactions and that this effect would be conserved among all three wild-type and mutant pairs. To accomplish this, we compared genes at 16 HAI between each wild-type and mutant pair for the previously defined fold change categories
( 2 to 3,3 to 4,4 to 5,5 to 10 , and $>10$ ). It follows that we can identify genes with lower fold change in mutant as compared with wild type or the reverse by observing the off-diagonal enrichment of differentially expressed genes. The results are summarized in Figure 4A. Suppression of regulation in the mutant as compared with wild type is shown in the upper right quadrant (dark gray) and induction in the mutant as compared with wild type in the lower left quadrant (light gray). The diagonal represents genes conserved within a fold change category between a wild-type and mutant pair. Interestingly, we found that all three paired wild-type and mutant alleles of Mla have between 2.7 to 5.4 times as many genes suppressed in mla relative to Mla as compared with the reverse. Specifically, 229 genes were suppressed in mlal-m508 as opposed to 85 in CI 16137 (Mlal), 239 genes were suppressed in mla6- $m 9472$ versus 85 genes in CI 16151 (Mla6), and lastly, 222 genes were suppressed in mla12-m66 versus 41 in Sultan-5 (Mla12).

To control for the case that suppression may be associated with genotype-specific effects or minor differences that met the threshold cutoff but are not biologically relevant, we iden-

Table 1. Candidates for Mildew resistance locus a (Mla) transcriptional regulon based on quantitative suppression in three wild-type versus mutant pairings at $16 \mathrm{~h}$ after inoculation

\begin{tabular}{|c|c|c|c|c|c|c|c|}
\hline \multirow[b]{2}{*}{ Probe Set } & \multirow[b]{2}{*}{ Contig No. $^{\mathrm{a}}$} & \multicolumn{2}{|c|}{$\begin{array}{c}\text { Consensus expression } \\
\text { patterns }\end{array}$} & \multicolumn{4}{|c|}{ BLASTn or BLASTx reference information } \\
\hline & & Wild type & Mutant & Organism & Accession/locus & E-score & Annotation $^{\mathrm{b}}$ \\
\hline Contig5537_at & 5537 & $0+++++$ & $0+++++$ & Oryza sativa & Os07g01560.2 & $2.00 \mathrm{E}-69$ & $\begin{array}{l}\text { Monosaccharide transport } \\
\text { protein }\end{array}$ \\
\hline Contig11154_at & 11154 & $0+++++$ & $0++++0$ & Hordeum vulgare & Os02g03410.2 & 0 & $\begin{array}{l}\text { Calcium-dependent protein } \\
\text { kinase }\end{array}$ \\
\hline Contig10860_at & 10860 & $0+++++$ & $0+0+++$ & O. sativa & Os03g58980.1 & $5.00 \mathrm{E}-42$ & Germin-like protein \\
\hline Contig12724_at & 12724 & $0+++++$ & $0+0+++$ & O. sativa & Os03g03034.4 & $1.00 \mathrm{E}-122$ & $\begin{array}{l}\text { Flavonol synthase/flavanone 3- } \\
\text { hydroxylase }\end{array}$ \\
\hline Contig14304_at & 14304 & $0+++++$ & $0+0+++$ & O. sativa & Os10g 38470.1 & $8.00 \mathrm{E}-84$ & Glutathione $S$-transferase \\
\hline Contig2639_at & 2639 & $0+++++$ & $0+0+++$ & O. sativa & Os05g05680.1 & $1.00 \mathrm{E}-156$ & $\begin{array}{l}\text { 1-aminocyclopropane-1- } \\
\text { carboxylate oxidase }\end{array}$ \\
\hline EBem10_SQ002_I10_s_at & 29452 & $0+++++$ & $0+0+++$ & O. sativa & Os01g59660.2 & 0 & Transcription factor-GAMYB \\
\hline Contig3568_at & 3568 & $0+++++$ & $000+++$ & H. vulgare & Os02g17940.6 & $1.00 \mathrm{E}-131$ & $\begin{array}{l}\text { Iron/ascorbate-dependent } \\
\text { oxidoreductase }\end{array}$ \\
\hline Contig26368_at & 26368 & $0++++0$ & $0+++00$ & O. sativa & Os06g11450.1 & $5.00 \mathrm{E}-08$ & $\begin{array}{l}\text { RING-H2 finger protein } \\
\text { ATL3B precursor }\end{array}$ \\
\hline Contig9422_at & 9422 & $0+++0+$ & $000+0+$ & O. sativa & Os01g07870.1 & $1.00 \mathrm{E}-132$ & $\begin{array}{l}\text { Multidrug resistance-associated } \\
\text { protein MRP2 / ABC } \\
\text { transporter }\end{array}$ \\
\hline Contig4942_at & 4942 & $0+++00$ & $000+00$ & O. sativa & Os02g32520.2 & 0 & $\begin{array}{l}\text { Early responsive to dehydration } \\
1 \text { (ERD1) protein }\end{array}$ \\
\hline Contig8949_at & 8949 & $0++000$ & $000+00$ & O. sativa & Os03g17310.1 & 0 & $\begin{array}{l}\text { Calcium-transporting ATPase, } \\
\text { endoplasmic reticulum-type }\end{array}$ \\
\hline HF22G17r_at & 34443 & $0++000$ & $000+00$ & H. vulgare & BU989685 & $1.00 \mathrm{E}-128$ & Unknown \\
\hline Contig11285_at & 11285 & $0+0+++$ & $0+0+++$ & O. sativa & Os04g37600.1 & $1.00 \mathrm{E}-138$ & Phosphate carrier protein \\
\hline HV_CEb000 015 r2_s_at & 39931 & $0+0+++$ & $0+0+++$ & O. sativa & Os $10 \mathrm{~g} 38470.1$ & $8.00 \mathrm{E}-09$ & Glutathione $S$-transferase \\
\hline Contig5876_at & 5876 & $0+0+++$ & $000+0+$ & O. sativa & Os01g08110.1 & 0 & $\begin{array}{l}\text { Flavonol-3-O-glycoside-7-O- } \\
\text { glucosyltransferase } 1\end{array}$ \\
\hline Contig12286_s_at & 12286 & $0+0+0+$ & $000+00$ & O. sativa & Os06g35700.1 & 0 & Reticuline oxidase precursor \\
\hline HVSMEb0007D15r2_at & 41025 & $00++++$ & $00++++$ & O. sativa & Os06g45570.1 & $4.00 \mathrm{E}-15$ & VQ motif family protein \\
\hline HVSMEf0001H14r2_at & 42024 & $00++++$ & $00++++$ & Not applicable & n.a. & n.a. & Unknown \\
\hline Contig15548_at & 15548 & $00++++$ & $000+++$ & O. sativa & Os05g25210.1 & $1.00 \mathrm{E}-148$ & Chaperone protein dnaJ-related \\
\hline Contig3744_s_at & 3744 & $00++++$ & $000+++$ & O. sativa & Os04g58850.1 & $5.00 \mathrm{E}-71$ & $\begin{array}{l}\text { Harpin-induced protein } 1 \\
\text { domain containing protein }\end{array}$ \\
\hline Contig8468_at & 8468 & $00+++0$ & $00++00$ & O. sativa & Os01g38980.2 & $1.00 \mathrm{E}-117$ & Calmodulin binding protein \\
\hline Contig24439_at & 24439 & $00+++0$ & $000+00$ & O. sativa & Os02g43430.1 & $6.00 \mathrm{E}-68$ & Protein kinase, putative \\
\hline Contig13091_s_at & 13091 & $00++0+$ & $000+00$ & O. sativa & Os06g50390.1 & 7.00E-16 & $\begin{array}{l}\text { Aspartic-type endopeptidase/ } \\
\text { pepsin A }\end{array}$ \\
\hline Contig10615_at & 10615 & $00+000$ & 000000 & O. sativa & Os03g07400.1 & $3.00 \mathrm{E}-36$ & Unknown protein \\
\hline HV_CEa0009C05r2_s_at & 39626 & $000+0+$ & $0000++$ & O. sativa & OJ1117_G01.1 & $1.00 \mathrm{E}-138$ & Expressed protein \\
\hline Contig21659_s_at & 21659 & 0000++ & 0000++ & O. sativa & Os11g37700.1 & $1.00 \mathrm{E}-36$ & PDR-type $\mathrm{ABC}$ transporter \\
\hline Contig2170_at & 2170 & $0000++$ & $0000++$ & Triticum aestivum & Q01482 & $9.00 \mathrm{E}-08$ & WIR1A protein \\
\hline
\end{tabular}

a Affymetrix Barley1 GeneChip contig numbers.

${ }^{b}$ Consensus annotation based on six BLASTn or BLASTx methods: i) BLASTx UniProt: Uniref90 (July 09), ii) BLASTn The Institute for Genomic Research (TIGR) plant transcript assemblies: TIGR TA Hordeum vulgare release 2, iii) BLASTx rice genome: TIGR release 6.1, iv) BLASTx National Center for Biotechnology Information (NCBI) reference sequence: NCBI RefSeq rel-35, v) BLASTn DFCI Hordeum vulgare gene index: HvGI (Dana Farber Cancer Institute) release 10, and vi) BLASTx Arabidopsis thaliana genome: TAIR release 9. 
tified those genes that were conserved in all three wild-type versus loss-of-function mutant pairs. Shown as a Venn diagram in Figure 4C, 28 genes were suppressed at $16 \mathrm{HAI}$ in all compatible interactions relative to incompatible interactions (Table 1; Supplementary Table S2). Annotation of these genes revealed a broad set of functional roles, involving redox homeostasis, signal transduction, energy transfer, proteolysis, protein folding, transport, ethylene biosynthesis, protein degradation, defense, transcription, and several genes with unknown function. Strikingly, all genes identified are induced after inoculation with $B$. graminis $\mathrm{f}$. $\mathrm{sp}$. hordei, with a diversity of patterns that include early, mixed, and late responses. Thus, increased expression was associated with wild-type Mla, as compared with the paired mla mutant for all 28 genes. As candidates of the MLA transcriptional regulon, this implicates MLA as an activator of gene expression (Shen et al. 2007). Though indirect, this asso-

Table 2. Downstream targets associated with resistance or susceptibility based on quantitative suppression in three wild-type versus mutant pairings at $32 \mathrm{~h}$ after inoculation

\begin{tabular}{|c|c|c|c|c|c|c|c|}
\hline \multirow[b]{2}{*}{ Probe Set } & \multirow[b]{2}{*}{ Contig no. ${ }^{\mathrm{a}}$} & \multicolumn{2}{|c|}{$\begin{array}{c}\text { Consensus expression } \\
\text { patterns }\end{array}$} & \multicolumn{4}{|c|}{ BLASTn or BLASTx reference information } \\
\hline & & Wild type & Mutant & Organism & Accession/locus & E-score & Consensus Annotation $^{b}$ \\
\hline \multicolumn{8}{|l|}{ Resistant Association } \\
\hline Contig7933_at & 7933 & $0+++++$ & $0+0+++$ & Oryza sativa & Os03g04110.1 & $2.00 \mathrm{E}-93$ & $\begin{array}{l}\text { LysM domain-containing GPI- } \\
\text { anchored protein precursor }\end{array}$ \\
\hline Contig10585_at & 10585 & $0+++++$ & $0+0+++$ & O. sativa & Os06g12250.1 & $1.00 \mathrm{E}-145$ & $\begin{array}{l}\text { Sphingolipid C4-hydroxylase } \\
\text { SUR2 }\end{array}$ \\
\hline Contig10887_at & 10887 & $0++++$ & $0+0+++$ & O. sativa & Os04g11820.1 & 0 & $\begin{array}{l}\text { White-brown complex } \\
\text { homolog protein }\end{array}$ \\
\hline Contig12794_at & 12794 & $0+++++$ & $0+0+++$ & O. sativa & TC179812 & $1.00 \mathrm{E}-129$ & Expressed protein \\
\hline Contig9422_at & 9422 & $0+++0+$ & $000+0+$ & O. sativa & Os01g07870.1 & $1.00 \mathrm{E}-132$ & $\mathrm{ABC}$ transporter family protein \\
\hline Contig6539_s_at & 6539 & $0+0+++$ & $0+0+++$ & O. sativa & Os02g33110.1 & $1.00 \mathrm{E}-145$ & Cell wall invertase \\
\hline Contig14426_at & 14426 & $0+0+++$ & $0+0+++$ & O. sativa & Os09g25150.3 & $8.00 \mathrm{E}-54$ & Cinnamoyl-CoA reductase \\
\hline Contig24409_at & 24409 & $0+0+++$ & $0+0+++$ & O. sativa & Os06g15760.1 & $1.00 \mathrm{E}-32$ & $\begin{array}{l}\text { Eukaryotic aspartyl protease } \\
\text { domain containing protein }\end{array}$ \\
\hline Contig406_at & 406 & $0+0+++$ & $0+0++0$ & O. sativa & Os08g38900.1 & $1.00 \mathrm{E}-102$ & $\begin{array}{l}\text { Caffeoyl-CoA O-methyltrans- } \\
\text { ferase }\end{array}$ \\
\hline Contig18290_at & 18290 & $0+0+++$ & $0+000+$ & Hordeum vulgare & TC170053 & $1.00 \mathrm{E}-111$ & Unknown \\
\hline Contig406_s_at & 406 & $0+0+++$ & $000+++$ & O. sativa & Os08g38900.1 & $1.00 \mathrm{E}-102$ & $\begin{array}{l}\text { Caffeoyl-CoA O-methyltrans- } \\
\text { ferase }\end{array}$ \\
\hline Contig3563_at & 3563 & $0+0+++$ & $000+++$ & O. sativa & Os02g17940.6 & $5.00 \mathrm{E}-62$ & $\begin{array}{l}\text { Leucoanthocyanidin } \\
\text { dioxygenase }\end{array}$ \\
\hline Contig6967_at & 6967 & $0+0+++$ & $000+0+$ & O. sativa & Os11g47820.1 & 0 & $\begin{array}{l}\text { Glucan endo-1,3-beta-glucosi- } \\
\text { dase precursor }\end{array}$ \\
\hline Contig4676_at & 4676 & $0+0++0$ & $0+0++0$ & O. sativa & Os02g08100.1 & 0 & 4-coumarate coenzyme A ligase \\
\hline Contig14427_at & 14427 & $0+0+00$ & $0+0000$ & O. sativa & Os06g35650.1 & $1.00 \mathrm{E}-138$ & $\begin{array}{l}\text { Reticuline oxidase-like protein } \\
\text { precursor }\end{array}$ \\
\hline HVSMEf0019011r2_at & 42715 & $0+0000$ & $0000+0$ & O. sativa & Os12g04120.1 & $6.00 \mathrm{E}-19$ & Phosphoglycerate mutase \\
\hline Contig14713_at & 14713 & 00++++ & $0+0+++$ & O. sativa & Os01g15029.1 & $5.00 \mathrm{E}-16$ & Unknown \\
\hline Contig15493_at & 15493 & $00++++$ & $0+0+++$ & O. sativa & Os06g 14490 & $3.00 \mathrm{E}-31$ & $\begin{array}{l}\text { Calmodulin-binding heat- } \\
\text { shock protein }\end{array}$ \\
\hline Contig13615_at & 13615 & $00++++$ & $00++0+$ & O. sativa & Os02g07690.1 & $4.00 \mathrm{E}-26$ & VQ domain containing protein \\
\hline Contig16910_at & 16910 & $00++++$ & $00++0+$ & H. vulgare & TC182261 & 0 & $\begin{array}{l}\text { Weakly similar to } \\
\text { UniRef100_Q3HTK6 Cluster }\end{array}$ \\
\hline Contig3564_s_at & 3564 & $00++++$ & $000+0+$ & O. sativa & Os02g17940.6 & $1.00 \mathrm{E}-128$ & $\begin{array}{l}\text { Leucoanthocyanidin } \\
\text { dioxygenase }\end{array}$ \\
\hline Contig20294_at & 20294 & $00++++$ & $000+0+$ & O. sativa & Os09g15330.2 & $5.00 \mathrm{E}-53$ & $\begin{array}{l}\text { Transporter family protein, } \\
\text { putative, expressed }\end{array}$ \\
\hline Contig14032_at & 14032 & $00++00$ & $000+00$ & O. sativa & Os12g06180.1 & $4.00 \mathrm{E}-91$ & HVA22 \\
\hline Contig15715_at & 15715 & 000-0- & 000--- & O. sativa & Os02g54360.1 & $8.00 \mathrm{E}-57$ & $\begin{array}{l}\text { Enzyme of the cupin super- } \\
\text { family protein }\end{array}$ \\
\hline Contig10150_at & 10150 & 000-0- & 0000-- & H. vulgare & TC169848 & 0 & $\begin{array}{l}\text { Weakly similar to } \\
\text { UniRef100_Q2IMJ3 cluster }\end{array}$ \\
\hline Contig14570_at & 14570 & 000-0- & 000000 & O. sativa & Os10g 33250.2 & $6.00 \mathrm{E}-56$ & WAX2 \\
\hline Contig7663_at & 7663 & $000-00$ & $000-00$ & O. sativa & Os12g01370.1 & 0 & Omega-3 fatty acid desaturase \\
\hline Contig11163_at & 11163 & $000-00$ & 000000 & O. sativa & Os10g42620.1 & $7.00 \mathrm{E}-63$ & $\begin{array}{l}\text { Cinnamoyl-CoA reductase- } \\
\text { related }\end{array}$ \\
\hline Contig5942_at & 5942 & $000+++$ & $0+0+++$ & O. sativa & Os04g44870.1 & $2.00 \mathrm{E}-64$ & $\mathrm{C} 2$ domain containing protein \\
\hline Contig4833_at & 4833 & $000+++$ & $0+00++$ & O. sativa & Os03g42110.1 & 0 & $\begin{array}{l}\text { Semialdehyde dehydrogenase, } \\
\text { NAD binding domain con- } \\
\text { taining protein }\end{array}$ \\
\hline Contig1737_at & 1737 & 000+++ & 000+++ & O. sativa & Os03g49380.1 & 0 & Lipoxygenase \\
\hline Contig8900_at & 8900 & $000+++$ & $000+++$ & O. sativa & Os09g32550.2 & 0 & $\begin{array}{l}\text { Glucan endo-1,3-beta-glucosi- } \\
\text { dase precursor }\end{array}$ \\
\hline Contig9086_at & 9086 & $000+++$ & $000+++$ & O. sativa & Os01g70380.1 & 0 & $\begin{array}{l}\text { Serine palmitoyltransferase } 2 \\
\quad(\text { continued on the next page })\end{array}$ \\
\hline
\end{tabular}

a Affymetrix Barley1 GeneChip contig numbers.

${ }^{b}$ Consensus annotation based on six BLASTn or BLASTx methods: i) BLASTx UniProt: Uniref90 (July 09), ii) BLASTn The Institute for Genomic Research (TIGR) plant transcript assemblies: TIGR TA Hordeum vulgare release 2, iii) BLASTx Rice genome: TIGR release 6.1, iv) BLASTx National Center for Biotechnology Information (NCBI) reference sequence: NCBI RefSeq rel-35, v) BLASTn DFCI Hordeum vulgare Gene Index: HvGI (Dana Farber Cancer Institute release 10, and vi) BLASTx Arabidopsis thaliana genome: TAIR release 9.

${ }^{\mathrm{c}}$ Annotation based on information from the BluGen website. 
ciation and the functional annotations of these targets provide additional support for these genes as candidates for MLA-mediated transcriptional activation.

The signaling cascades at $16 \mathrm{HAI}$ and later timepoints control both the transcriptional and phenotypic outcomes of the barley-B. graminis f. sp. hordei interaction. It follows that genes associated with resistance at later timepoints may iden- tify downstream targets of this primary signaling cascade or transcriptome reprogramming related to post-resistance mechanisms. We found a similar effect at $32 \mathrm{HAI}$ as compared with $16 \mathrm{HAI}$, where quantitative suppression of expression in mutant mla alleles as compared with wild-type Mla predominated all three paired compatible and incompatible interactions. In total, 66 genes were associated with resistance, with 45 genes induced

Table 2. (continued from the previous page)

\begin{tabular}{|c|c|c|c|c|c|c|c|}
\hline \multirow[b]{2}{*}{ Probe Set } & \multirow[b]{2}{*}{ Contig no. ${ }^{\mathrm{a}}$} & \multicolumn{2}{|c|}{$\begin{array}{c}\text { Consensus expression } \\
\text { patterns }\end{array}$} & \multicolumn{4}{|c|}{ BLASTn or BLASTx reference information } \\
\hline & & Wild type & Mutant & Organism & Accession/locus & E-score & Consensus Annotation $^{b}$ \\
\hline Contig12590_at & 12590 & $000+++$ & $000+++$ & O. sativa & Os01g72530.1 & $3.00 \mathrm{E}-49$ & $\begin{array}{l}\text { Calmodulin-related calcium } \\
\text { sensor protein }\end{array}$ \\
\hline Contig13144_at & 13144 & $000+++$ & $000+++$ & O. sativa & Os11g05880.1 & 0 & Exocyst complex subunit \\
\hline HVSMEm0005J13r2_at & 45474 & $000+++$ & $000+++$ & O. sativa & Os06g07200.1 & $1.00 \mathrm{E}-48$ & Syntaxin \\
\hline S0000700018E12F1_s_at & 51485 & $000+++$ & $000+++$ & Triticum aestivum & TC156523 & $2.00 \mathrm{E}-84$ & Alkaline invertase \\
\hline Contig17964_at & 17964 & $000+++$ & $000+0+$ & O. sativa & Os03g18560.1 & $7.00 \mathrm{E}-79$ & $\begin{array}{l}\text { DUF538 domain containing } \\
\text { protein }\end{array}$ \\
\hline Contig6380_at & 6380 & $000+++$ & $0000++$ & O. sativa & Os11g08100.1 & $1.00 \mathrm{E}-179$ & $\begin{array}{l}\text { Eukaryotic aspartyl protease } \\
\text { domain containing protein }\end{array}$ \\
\hline Contig12360_at & 12360 & $000+0+$ & $000++0$ & O. sativa & Os02g46962.3 & $7.00 \mathrm{E}-88$ & $\begin{array}{l}\text { VHS and GAT domain } \\
\text { containing protein }\end{array}$ \\
\hline Contig10151_s_at & 10151 & 0000-- & 0000-- & H. vulgare & TC169848 & $2.00 \mathrm{E}-99$ & $\begin{array}{l}\text { Weakly similar to } \\
\text { UniRef100_Q2IMJ3 cluster }\end{array}$ \\
\hline Contig15701_at & 15701 & 0000-- & 0000-- & O. sativa & Os03g59070.1 & $3.00 \mathrm{E}-18$ & $\begin{array}{l}\text { Phosphatase, putative, } \\
\text { expressed }\end{array}$ \\
\hline HY03H15u_s_at & 48271 & 0000-- & $00000-$ & H. vulgare & TA36935_4513 & 0 & $\begin{array}{l}\text { Putative CENP-E like } \\
\text { kinetochore protein }\end{array}$ \\
\hline Contig20750_at & 20750 & $0000++$ & $000+0+$ & O. sativa & Os03g47034.1 & $8.00 \mathrm{E}-19$ & Unknown \\
\hline Contig10205_at & 10205 & 00000- & $000--0$ & O. sativa & Os04g50710.1 & $3.00 \mathrm{E}-36$ & $\begin{array}{l}\text { Pathogenesis-related Bet v I } \\
\text { family protein }\end{array}$ \\
\hline Contig14611_at & 14611 & 00000- & 0000-- & O. sativa & Os12g37710.1 & $2.00 \mathrm{E}-92$ & PsbP \\
\hline Contig10822_at & 10822 & $00000-$ & 0000-0 & O. sativa & Os03g45400.1 & $8.00 \mathrm{E}-82$ & $\begin{array}{l}\text { Antitermination NusB domain- } \\
\text { containing protein }\end{array}$ \\
\hline Contig11917_at & 11917 & $00000-$ & $00000-$ & O. sativa & Os01g10810.1 & $5.00 \mathrm{E}-38$ & $\begin{array}{l}\text { Rho termination factor, } \\
\text { N-terminal domain containing } \\
\text { protein }\end{array}$ \\
\hline HF01F13w_s_at & 33960 & 00000- & 00000- & O. sativa & Os01g65780.4 & $2.00 \mathrm{E}-13$ & Glycosyl transferase \\
\hline Contig5988_at & 5988 & 00000- & 000000 & O. sativa & Os03g25960.1 & $1.00 \mathrm{E}-80$ & $\begin{array}{l}\text { RNA recognition motif con- } \\
\text { taining protein }\end{array}$ \\
\hline Contig7032_at & 7032 & 00000- & 000000 & O. sativa & Os04g54810.1 & 0 & Beta-D-xylosidase \\
\hline Contig12100_at & 12100 & 00000- & 000000 & H. vulgare & BF627497 & 0 & \\
\hline Contig16570_at & 16570 & 00000- & 000000 & O. sativa & Os02g35230.1 & $1.00 \mathrm{E}-42$ & Unknown \\
\hline Contig18909_at & 18909 & 00000- & 000000 & O. sativa & Os03g07120.1 & $1.00 \mathrm{E}-101$ & Unknown \\
\hline Contig25506_at & 25506 & 00000- & 000000 & H. vulgare & BI778169 & $1.00 \mathrm{E}-180$ & Unknown \\
\hline HVSMEb0011L02r2_s_at & 41192 & 00000- & 000000 & O. sativa & TA44824_4513 & $1.00 \mathrm{E}-49$ & Hypothetical protein \\
\hline Contig10709_at & 10709 & $00000+$ & $0000++$ & O. sativa & Os06g03580.2 & $8.00 \mathrm{E}-55$ & Zinc RING finger protein \\
\hline Contig15880_at & 15880 & $00000+$ & $00000+$ & O. sativa & Os12g09000.2 & $6.00 \mathrm{E}-76$ & $\begin{array}{l}\text { Phosphomethylpyrimidine } \\
\text { kinase/thiamin-phosphate } \\
\text { pyrophosphorylase }\end{array}$ \\
\hline Contig21643_at & 21643 & $00000+$ & $00000+$ & O. sativa & Os03g04570.1 & $3.00 \mathrm{E}-73$ & Peptide transporter PTR3-A \\
\hline Contig12469_at & 12469 & $00000+$ & 000000 & O. sativa & Os03g0188500 & $1.00 \mathrm{E}-160$ & Expressed protein \\
\hline Contig12629_s_at & 12629 & $00000+$ & 000000 & O. sativa & Os01g49529.3 & $1.00 \mathrm{E}-147$ & $\begin{array}{l}\text { Receptor-like cytoplasmic } \\
\text { kinase OsWAK-RLCK }\end{array}$ \\
\hline Contig14625_at & 14625 & $00000+$ & 000000 & H. vulgare & TC174003 & 0 & Unknown \\
\hline HF06A04r_at & 34067 & $00000+$ & 000000 & H. vulgare & BU985056 & 0 & Unknown \\
\hline Contig16710_at & 16710 & 000000 & $0+0000$ & O. sativa & Os07g18230.1 & $1.00 \mathrm{E}-77$ & Lectin-like receptor kinase \\
\hline EBro02_SQ004_C14_at & 30414 & 000000 & $000+00$ & H. vulgare & TA53062_4513 & $1.00 \mathrm{E}-142$ & \\
\hline Contig12640_at & 12640 & 000000 & 0000-0 & O. sativa & Os01g69120.1 & $1.00 \mathrm{E}-43$ & $\begin{array}{l}\text { Uncharacterized RNA } \\
\text { methyltransferase pc1998 }\end{array}$ \\
\hline \multicolumn{8}{|l|}{ Susceptible Association } \\
\hline HVSMEm0013N06r2_at & 45705 & $0+00+0$ & $0+000+$ & $\begin{array}{l}\text { Blumeria } \\
\text { graminis }^{\mathrm{c}}\end{array}$ & BI953678 & $1.00 \mathrm{E}-88$ & Hypothetical protein \\
\hline HO09D16S_at & 36134 & $00+0+0$ & $00++++$ & B. graminis & TC175543 & 0 & Unknown \\
\hline HO10J02S_at & 36228 & $00+000$ & 000000 & B. graminis & TC172857 & 0 & Unknown \\
\hline HVSMEl0002L06r2_at & 44740 & 000--0 & 0000-- & O. sativa & Os03g03670.1 & $3.00 \mathrm{E}-35$ & Hypothetical protein \\
\hline Contig5378_at & 5378 & $0000+0$ & $0000++$ & O. sativa & Os09g12600.1 & $1.00 \mathrm{E}-163$ & $\begin{array}{l}\text { Phosphate/phosphate } \\
\text { translocator }\end{array}$ \\
\hline HVSMEl0014B21r2_at & 45091 & 000000 & $000+0+$ & H. vulgare & BI949476 & $1.00 \mathrm{E}-100$ & Expressed protein \\
\hline Contig4174_at & 4174 & 000000 & $00000+$ & O. sativa & Os05g33130.1 & $1.00 \mathrm{E}-109$ & $\begin{array}{l}\text { Chitinase family protein } \\
\text { precursor }\end{array}$ \\
\hline Contig25983_at & 25983 & 000000 & $00000+$ & B. graminis & BE214522 & 0 & Hypothetical protein \\
\hline
\end{tabular}


and 21 genes suppressed in response to $B$. graminis f. sp. horde $i$ challenge (Fig. 4B and C). As summarized in Table 2, an even greater diversity of functional roles was identified, revealing the complexity associated with downstream responses to $B$. graminis f. sp. hordei challenge.

So far, our analyses have focused on gene expression associated with resistance, i.e., genes with lower expression in mla mutants as compared with wild type. We also identified genes that had greater expression in mutant mla versus wild-type Mla. The expression of these eight genes was associated with susceptibility at $32 \mathrm{HAI}$ (Table 2). Functional annotation of these genes established that four were fungal in origin (Spanu et al. 2010), arising from several expressed sequence tag libraries derived from barley tissue inoculated with powdery mildew during the design phase of the Barley1 GeneChip (Close et al. 2004). One of the four fungal genes (represented by HVSMEm0013N06r2_at) was the only gene associated with susceptibility at 16 HAI. It is difficult to ascertain the significance of this association, as these few are a subset of those $B$. graminis f. sp. hordei probe sets that remain on the Barley 1 GeneChip due to stringent filtering of fungal sequences (Close et al. 2004). However, their identification does demonstrate that our approach for detecting quantitative expression differences associated with susceptibility reflects the potential for colonization of $B$. graminis $\mathrm{f}$. sp. hordei on the surface of barley leaves.

\section{DISCUSSION}

Our molecular understanding of plant-pathogen interactions is most complete at the level of perception. A primary component of this perception is the recognition of pathogen-associated molecular patterns (PAMPs) (Jones and Dangl 2006). PAMP recognition receptors, located at the cell periphery or the plasma membrane, initiate a signal transduction cascade in the host that produces the innate immune response (Jones and Dangl 2006). To counter this, pathogens have within their repertoire a diverse set of effectors that act as inhibitors of PAMPmediated resistance. Plants have evolved effective countermeasures by elevating the mechanism of perception from nonspecific recognition of PAMPs to specific recognition of AVR effectors via resistance (R) proteins (Jones and Dangl 2006).

In vitro and in vivo interaction assays have pointed to an intermolecular complex composed of MLA, RAR1, SGT1, and HSP90 (Azevedo et al. 2002, 2006; Bieri et al. 2004; Zhang et al. 2008), demonstrating that these components are involved in $\mathrm{R}$ protein stability and signal transduction after recognition but not necessarily the initiation of the HR. Yet, the mechanistic link between MLA and WRKY1/2 implicates a role for transcriptional regulation in mediating the HR (Shen et al. 2007). Concordantly, a small fraction of MLA protein in the nucleus of noninoculated plants overexpressing a MLA-YFP fusion was detected (Dangl 2007; Shen et al. 2007). Hence, the quantitative kinetics of MLA localization may determine the qualitative phenotype through a threshold mechanism in which the presence of the appropriate $\mathrm{AVR}_{\mathrm{a}}$ effector significantly perturbs the balance of cytoplasmic- and membrane-localized and nuclear-localized MLA. It follows that the fluctuating rates of nuclear import or export may influence the transcript levels of MLA targets. This balance could be altered by the residual presence of unrecognized AVR protein in compatible interactions of the type $\mathrm{MLA}_{\mathrm{x}}-\mathrm{AVR}_{\mathrm{y}}$, in which the mispairing of $\mathrm{MLA}_{\mathrm{x}}$ with $\mathrm{AVR}_{\mathrm{y}}$ affects the localization of MLA, resulting in a compatible interaction but still regulates the same set of genes (Caldo et al. 2004, 2006). The balance could also be perturbed by a null (mlal-m508 and mla6-m9472) or loss-offunction (mla12-m66) mutation in the MLA protein, as would be the case in the current experiment involving Mla mutants. In this case, the AVR effector does not bind with its intended MLA target, resulting in altered programming of the expected defense cascade.

We identified 28 candidates of the MLA transcriptional regulon by characterizing genes at $16 \mathrm{HAI}$ that were quantitatively upregulated in plants containing three diverse wild-type Mla alleles as compared with their respective loss-of-function mutants. Since it is known WRKY1/2 are repressors of basal defense, we hypothesized that MLA acts primarily as an activator of gene expression. It is expected, then, that the candidates of the MLA transcriptional regulon would overlap with basal defense processes, regulated in part by pattern recognition receptor-mediated signaling, functionally associated with defense, or both (Jones and Dangl 2006). Several of the geneexpression patterns and annotations matched our previous expectations. Of the genes involved in redox homeostasis, Contig10860_at is predicted to encode a germin-like protein that has the majority of its sequence information contributed by cDNA libraries of powdery mildew-inoculated tissue. Though it has yet to be characterized in the barley- $B$. graminis f. sp. hordei interaction, several other members of this protein family are both positively and negatively associated with resistance (Himmelbach et al. 2010). Their direct involvement in defense has been attributed to their production of hydrogen peroxide from superoxide dismutase or oxalate-oxidase activity, or both (Himmelbach et al. 2010). Genes involved in signal transduction have been analyzed using the same family-wise approach used with germin-like proteins, with the initial characterization of the calcium-dependent protein kinases (CDPK) family (Freymark et al. 2007). The CDPK of barley also modulate resistance to $B$. graminis f. sp. hordei in a variety of contexts, such as mlo and basal penetration resistance. Identification of HvCDPK5 (Contig11154_at) in our analysis at $16 \mathrm{HAI}$ implicates its potential role in defense, although this gene was excluded in those tested by Freymark and colleagues (2007), as it did not have a full-length coding sequence.

The quantitative differences observed among wild-type Mla and loss-of-function mutants are reminiscent of differences observed between susceptible plants carrying wild-type Mlo and resistant mlo mutants (Zierold et al. 2005). Moreover, there was an overlap in four (HO06K23, HO12F09, HO03A06, HO15N08) of the 39 genes reported by Zierold and colleagues (2005) as being associated with resistance. In particular, this includes Contig9422_at (HO03A06), a predicted multiple resistance-associated protein-like ABC transporter in which greater expression is associated with resistance at 16 , 24, and 32 HAI (Tables 1 and 2). Of the remaining genes, three have been identified previously by their transcriptional profile during the barley- $B$. graminis $\mathrm{f}$. $\mathrm{sp}$. hordei interaction. HV_CEb0004O15r2_s_at and Contig12286_s_at are predicted to encode a glutathione $S$-transferase (GST) and a reticuline oxidase precursor, respectively, as correlated kinetically with resistance by Caldo and colleagues (2004, 2006). Contig4942_at (Early Responsive to Dehydration 1 [ERD1] homolog) was identified by Jansen and associates (2005), using a differential screening approach between paired near-isogenic $M l g$ (CI 16139) and $\mathrm{mlg}$ (CI 16140) plants in cv. Manchuria background. ERD1 is known to be induced in Arabidopsis thaliana by water stress and during senescence (Nakashima et al. 1997) and is induced in barley by both $B$. graminis f. sp. hordei challenge and treatment with the resistance-inducing chemical benzothiadiazole (Jansen et al. 2005).

The diverse biological roles and early induction of these candidates substantiate several hypotheses associated with downstream transcriptional targets of MLA R proteins (Bent and Mackey 2007; Mur et al. 2008; Shen et al. 2007). One hy- 
pothesis is based on the interaction of MLA with repressors of basal defense, suggesting that candidate gene targets overlap with genes involved in PAMP-triggered immunity (Jones and Dangl 2006; Shen et al. 2007). Three lines of evidence support an association with PAMP-triggered immunity. First, 17 of the 28 were induced by $8 \mathrm{HAI}$, implicating their early role in the defense response. Second, functional annotation reflects a direct overlap with known roles in plant-pathogen interactions (e.g., CDPK, GST, germin-like proteins, ATPase). Interestingly, the detection of GST as a significant candidate by Caldo and colleagues (2004) and here suggests that it may be an essential target of MLA regulation or that its expression is hypersensitive to MLA relocalization, or both. Third, activation of gene expression was only observed after MLA nuclear localization. Credibility for the association of these genes with MLA regulation was reinforced by the interrogation of both the 16 and 32 HAI timepoints, at which transcripts of several $B$. graminis f. sp. hordei genes present on the Barley1 GeneChip were significantly upregulated on susceptible mla mutants.

The generation of a comprehensive index of differentially expressed genes and incorporation of fold change provided a global overview of the transcriptome reprogramming in the context of incompatible and compatible interactions. A significant differential response was observed in plants harboring mla loss-of-function mutations, correlating with the establishment of $B$. graminis f. sp. hordei haustoria and resulting in a compatible interaction. This response was not sustained, as the number of genes with expression in the upper fold-change categories ( 5 to 10 and $>10$ ) was either unchanged in later timepoints or significantly reduced. This result is somewhat similar to an observation in the grape-powdery mildew interaction, in which resistant varieties had very few differentially expressed genes as compared with susceptible varieties (Fung et al. 2008). In contrast to the grape-powdery mildew system, barley-B. graminis f. sp. hordei incompatible interactions displayed an ever-increasing expression response. One biological model fitting these observations would implicate MLA as a steady-state suppressor of defense gene activation at $20 \mathrm{HAI}$, although it is unclear whether this proposed inhibitory role would be in parallel to or distinct from known gene activation (Shen et al. 2007). That said, this model is restricted to transcriptional cascades associated with MLA signaling. An alternative model involves effector-mediated transcriptome reprogramming in the host at $20 \mathrm{HAI}$ and would explain the apparent transcriptional response in plants carrying a loss-of-function mla allele.

In considering further work to distinguish between these possibilities, we are aware that a potentially limiting factor has been the use of seedling first leaves (PO:0007094) compared with analyzing mRNA amplified from single cells (Chandran et al. 2010; Gjetting et al. 2004, 2007), distinct epidermal or mesophyll tissues (Zierold et al. 2005), or even nuclear versus mitochondrial or chloroplast subcellular fractions. Even in the absence of such cell sampling approaches, the stronger induction at $20 \mathrm{HAI}$ in loss-of-function mla genotypes and identification of candidate genes for the MLA transcriptional regulon provides another regulatory link between innate immunity and the early role of MLA in reprogramming the transcriptional response to powdery mildew.

\section{MATERIALS AND METHODS}

\section{Fungal material.}

B. graminis f. sp. hordei isolate 5874 (Torp et al. 1978; Wei et al. 1999) $\left(A V R_{a 1}, A V R_{a 6}, A V R_{a 12}\right)$ was propagated on barley (Hordeum vulgare) cv. Manchuria (CI 2330) in a controlledgrowth chamber with $16 \mathrm{~h}$ (4:00 to 11:59 PM U.S. Central standard time) of light and $8 \mathrm{~h}(12: 00 \mathrm{AM}$ to $3: 59 \mathrm{PM})$ of darkness at $18^{\circ} \mathrm{C}$.

\section{Plant material.}

CI 16137 (Mlal) and CI 16151 (Mla6) are near-isogenic lines in the six-row barley cv. Manchuria (Moseman 1972). Mla deletion mutants, mlal-m508 and mla6-m9472, are derived from $\gamma$ irradiation and fast neutron mutagenesis of CI 16137 and CI 16151, respectively (Meng et al. 2009; Zhou et al. 2001). The two-row barley cv. Sultan-5 harbors the Mla12 resistance allele and the derived Mla12 point mutant, mla12-m66, was generated by ethylmethane sulfonate mutagenesis (Shen et al. 2003; Torp and Jørgensen 1986). mla1-m508 was a gift from S. Somerville (University of California, Berkeley, CA, U.S.A.), mla6-9472 was generated by the Wise lab (United States Department of Agriculture-Agricultural Research Service [USDA-ARS], Iowa State University, Ames, IA, U.S.A.) (Meng et al. 2009), and Sultan-5 and mla12-m66 were provided by J. Helms Jørgensen (Ris $\varnothing$ National Laboratory, Roskilde, Denmark). Wild-type Mla lines and respective mutants have been maintained by at least 10 generations of selfing, essentially fixing any second-site mutations; however, the lack of Mla specificity in the loss-of-function mutants is the primary determinant segregating for susceptibility.

\section{Experimental design.}

Planting, stage of seedlings, inoculation, and leaf tissue sampling were followed as described by Caldo and associates (2006). Two $20 \times 30-\mathrm{cm}$ trays per genotype of CI 16137, CI 16151, Sultan-5, mla1-m508, mla6-m9472, and mla12-m66 were planted in sterilized potting soil. One tray of seedlings was used for noninoculation control and the other was used for inoculation treatment for each genotype. Each experimental tray consisted of six rows of 15 seedling first leaves (PO:0007094), with rows randomly assigned to one of the six harvest times $(0,8,16,20,24$, and $32 \mathrm{HAI})$. The entire experiment was repeated three times in a split-split-plot design with genotype, inoculation type, and harvest time as whole-plot, split-plot, and split-split-plot factors, respectively.

\section{Target synthesis and GeneChip hybridization.}

Total RNA was isolated using a hot $\left(60^{\circ} \mathrm{C}\right)$ phenol/guanidine thiocyanate method (Caldo et al. 2004, 2006). Probe synthesis and labeling were performed at the Iowa State University GeneChip Core facility (Ames, IA, U.S.A.), using the One Cycle and GeneChip IVT labeling kits. The cRNA was fragmented and was used to make each hybridization cocktail containing $10 \%$ dimethyl sulfoxide, and an equivalent of $5 \mu \mathrm{g}$ was hybridized to Barleyl GeneChip probe arrays (Affymetrix 900515) (Close et al. 2004).

\section{Normalization and mixed linear model analysis.}

Normalization, data transformation, and mixed linear model analysis (Wolfinger et al. 2001) were patterned after the methods used by Caldo and colleagues $(2004,2006)$. The data were split into two datasets based on genetic background, cv. Sultan-5 or Manchuria, for the mixed model analysis. An estimate statement in SAS v9.1 was used to compare transcript levels between inoculated and noninoculated plants of a specific genotype per timepoint (SAS Institute Inc., Cary, NC, U.S.A.). FDR were determined for each estimate using a Python-implementation of the histogram-based algorithm described by Nettleton and associates (2006).

\section{Derivation of consensus patterns.}

By insisting on significance in at least four of the nine (three genotypes $\times$ three FDR levels) comparisons, we are guaranteed at a minimum that one of the following is true: 
i) Significance was obtained at the $0.0001 \%$ FDR level for at least one genotype with significance at the $1 \%$ level for at least one other genotype,

ii) Significance was obtained at the $0.01 \%$ level for at least two of the three genotypes, or

iii) Significance was obtained at the $0.01 \%$ level for at least one genotype with significance at the $1 \%$ level for the other two genotypes.

Note that if fewer than four significant results were required, it would be possible for a single genotype to determine the "consensus" pattern, which would obviously be undesirable.

\section{Data access.}

All original protocols and microarray data are available at the PLEXdb gene expression resource for plants and plant pathogens. Although the biological sampling, RNA extraction and GeneChip hybridizations were performed at the same time, data were uploaded as two experiments based on genetic background. Accession BB2 corresponds to the 180 GeneChips involving Sultan-5 and its derived mutants and BB10 designates the 144 GeneChips coming from Manchuria near-isogenic lines and loss-of-function mutants. GeneChip data files have also been deposited in ArrayExpress with accessions E-TABM82 (BB2 Sultan-5 experiment) and E-TABM-142 (BB10 Manchuria experiment).

\section{ACKNOWLEDGMENTS}

The authors thank A. Bogdanove for critical review of the manuscript, J. Peng (Iowa State University GeneChip facility) for his expertise in performing the GeneChip hybridizations, and G. Fuerst for preparation of the tables and figures. This article is a joint contribution of The Iowa Agriculture and Home Economics Experiment Station and the Corn Insects and Crop Genetics Research Unit, USDA-ARS. This work was supported by National Science Foundation-Plant Genome Award 0500461 to R. Wise and D. Nettleton, USDA-Initiative for Future Agriculture and Food Systems grant 2001-52100-11346 to R. Wise, and USDA-ARS CRIS \#362521000-049-00D to R. Wise and N. Lauter. All germplasm identifiers using a CI prefix refer to the nomenclature applied by the USDA National Plant Germplasm System. Mention of trade names or commercial products in this publication is solely for the purpose of providing specific information and does not imply recommendation or endorsement by the U.S. Department of Agriculture.

\section{LITERATURE CITED}

Azevedo, C., Sadanandom, A., Kitagawa, K., Freialdenhoven, A., Shirasu, K., and Schulze-Lefert, P. 2002. The RAR1 interactor SGT1, an essential component of $R$ gene-triggered disease resistance. Science 295:2073-2076

Azevedo, C., Betsuyaku, S., Peart, J., Takahashi, A., Noël, L., Sadanandom, A., Casais, C., Parker, J., and Shirasu, K. 2006. Role of SGT1 in resistance protein accumulation in plant immunity. EMBO (Eur. Mol. Biol. Organ.) J. 25:2007-2016.

Bent, A. F., and Mackey, D. 2007. Elicitors, effectors, and $R$ genes: The new paradigm and a lifetime supply of questions. Annu. Rev. Phytopathol. 45:399-436.

Bieri, S., Mauch, S., Shen, Q. H., Peart, J., Devoto, A., Casais, C., Ceron, F., Schulze, S., Steinbi $\beta$, H. H., Shirasu, K., and Schulze-Lefert, P. 2004. RAR1 positively controls steady state levels of barley MLA resistance proteins and enables sufficient MLA6 accumulation for effective resistance. Plant Cell 16:3480-3495.

Biffen, R. H. 1907. Studies in the inheritance of disease resistance. J. Agric. Sci. 2:109-128

Boyd, L. A., Smith, P. H., Foster, E. M., and Brown, J. K. M. 1995. The effects of allelic variation at the Mla resistance locus in barley on the early development of Erysiphe graminis f. sp. hordei and host responses. Plant J. 7:959-968.

Bushnell, W. R. 2002. The role of powdery mildew research in understanding host-parasite interaction: Past, present, and future. Pages 1-12 in: The Powdery Mildews: A Comprehensive Treatise, eds. American Phytopathological Society Press, St. Paul, MN, U.S.A.

Caldo, R. A., Nettleton, D., and Wise, R. P. 2004. Interaction-dependent gene expression in Mla-specified response to barley powdery mildew. Plant Cell 16:2514-2528.

Caldo, R. A., Nettleton, D., Peng, J., and Wise, R. P. 2006. Stage-specific suppression of basal defense discriminates barley plants containing fastand delayed-acting Mla powdery mildew resistance alleles. Mol. PlantMicrobe Interact. 19:939-947.

Chandran, D., Inada, N., Hather, G., Kleindt, C. K., and Wildermuth, M. C. 2010. Laser microdissection of Arabidopsis cells at the powdery mildew infection site reveals site-specific processes and regulators. Proc. Natl. Acad. Sci. U.S.A. 107:460-465.

Close, T. J., Wanamaker, S. I., Caldo, R. A., Turner, S. M., Ashlock, D. A. Dickerson, J. A., Wing, R. A., Muehlbauer, G. J., Kleinhofs, A., and Wise, R. P. 2004. A new resource for cereal genomics: 22K barley GeneChip comes of age. Plant Physiol. 134:960-968.

Collinge, D. B., Gregersen, P. L., and Thordal-Christensen, H. 2002. The nature and role of defense response genes in cereals. Pages 146-160 in: The Powdery Mildews: A Comprehensive Treatise, eds. American Phytopathological Society Press, St. Paul, MN, U.S.A.

Dangl, J. L. 2007. Plant science. Nibbling at the plant cell nucleus. Science 315:1088-1089.

Eichmann, R., Biemelt, S., Schäfer, P., Scholz, U., Jansen, C., Felk, A. Schäfer, W., Langen, G., Sonnewald, U., Kogel, K.-H., and Hückelhoven, R. 2006. Macroarray expression analysis of barley susceptibility and nonhost resistance to Blumeria graminis. J. Plant Physiol. 163:657-670.

Freymark, G., Diehl, T., Miklis, M., Romeis, T., and Panstruga, R. 2007. Antagonistic control of powdery mildew host cell entry by barley calcium-dependent protein kinases (CDPKs). Mol. Plant-Microbe Interact. 20:1213-1221.

Fung, R. W., Gonzalo, M., Fekete, C., Kovacs, L. G., He, Y., Marsh, E., McIntyre, L. M., Schachtman, D. P., and Qiu, W. 2008. Powdery mildew induces defense-oriented reprogramming of the transcriptome in a susceptible but not in a resistant grapevine. Plant Physiol. 146:236-249.

Gjetting, T., Carver, T. L., Skot, L., and Lyngkjaer, M. F. 2004. Differentia gene expression in individual papilla-resistant and powdery mildew-infected barley epidermal cells. Mol. Plant-Microbe Interact. 17:729-738.

Gjetting, T., Hagedorn, P. H., Schweizer, P., Thordal-Christensen, H., Carver, T. L., and Lyngkjaer, M. F. 2007. Single-cell transcript profiling of barley attacked by the powdery mildew fungus. Mol. Plant-Microbe Interact. 20:235-246.

Halterman, D. A., and Wise, R. P. 2004. A single-amino acid substitution in the sixth leucine-rich repeat of barley MLA6 and MLA13 alleviates dependence on RAR1 for disease resistance signaling. Plant J. 38:215226.

Himmelbach, A., Liu, L., Zierold, U., Altschmied, L., Maucher, H., Beier, F., Müller, D., Hensel, G., Heise, A., Schützendübel, A., Kumlehn, J., and Schweizer, P. 2010. Promoters of the barley germin-like GER4 gene cluster enable strong transgene expression in response to pathogen attack. Plant Cell 22:937-952.

Hu, P., Meng, Y., and Wise, R. P. 2009. Functional contribution of chorismate synthase, anthranilate synthase, and chorismate mutase to penetration resistance in barley-powdery mildew interactions. Mol. Plant-Microbe Interact. 22:311-320

Jansen, C., Korell, M., Eckey, C., Biedenkopf, D., and Kogel, K.-H. 2005. Identification and transcriptional analysis of powdery mildew-induced barley genes. Plant Sci. 168:373-380.

Jones, J. D., and Dangl, J. L. 2006. The plant immune system. Nature 444:323-329

Jørgensen, J. H. 1994. Genetics of powdery mildew resistance in barley. Crit. Rev. Plant Sci. 13:97-119.

Keddie, J. S., Carroll, B. J., Thomas, C. M., Reyes, M. E., Klimyuk, V., Holtan, H., Gruissem, W., and Jones, J. D. 1998. Transposon tagging of the Defective embryo and meristems gene of tomato. Plant Cell 10:877888.

Kuehl, R. O. 2000. Design of experiments: Statistical principles of research design and analysis. Duxbury Press, Pacific Grove, CA, U.S.A.

Meng, Y., Moscou, M. J., and Wise, R. P. 2009. Blufensin1 negatively impacts basal defense in response to barley powdery mildew. Plant Physiol. 149:271-285.

Moseman, J. G. 1972. Isogenic barley lines for reaction to Erysiphe graminis f. sp. hordei. Crop Sci. 12:681-682.

Mur, L. A., Kenton, P., Lloyd, A. J., Ougham, H., and Prats, E. 2008. The hypersensitive response; the centenary is upon us but how much do we know? J. Exp. Bot. 59:501-520.

Nakashima, K., Kiyosue, T., Yamaguchi-Shinozaki, K., and Shinozaki, K. 1997. A nuclear gene, erd1, encoding a chloroplast-targeted Clp protease regulatory subunit homolog is not only induced by water stress but also developmentally up-regulated during senescence in Arabidopsis thaliana. Plant J. 12:851-861.

Nettleton, D., Hwang, J. T. G., Caldo, R. A., and Wise, R. P. 2006. Estimating the number of true null hypotheses from a histogram of $p$-val- 
ues. J. Agricult. Biol. Env. Stat. 11:337-356.

Ridout, C. J., Skamnioti, P., Porritt, O., Sacristan, S., Jones, J. D., and Brown, J. K. 2006. Multiple avirulence paralogues in cereal powdery mildew fungi may contribute to parasite fitness and defeat of plant resustance. Plant Cell 18:24-1-2414.

Seeholzer, S., Tsuchimatsu, T., Jordan, T., Bieri, S., Pajonk, S., Yang, W., Jahoor, A., Shimizu, K. K., Keller, B., and Schulze-Lefert, P. 2010. Diversity at the Mla powdery mildew resistance locus from cultivated barley reveals sites of positive selection. Mol. Plant-Microbe Interact. 23:497-509.

Shen, Q. H., Zhou, F., Bieri, S., Haizel, T., Shirasu, K., and Schulze-Lefert, P. 2003. Recognition specificity and RAR1/SGT1 dependence in barley Mla disease resistance genes to the powdery mildew fungus. Plant Cell 15:732-744

Shen, Q. H., Saijo, Y., Mauch, S., Biskup, C., Bieri, S., Keller, B., Seki, H., Ulker, B., Somssich, I. E., and Schulze-Lefert, P. 2007. Nuclear activity of MLA immune receptors links isolate-specific and basal disease-resistance responses. Science 315:1098-1103.

Skamnioti, P., Pedersen, C., Al-Chaarani, G. R., Holefors, A., ThordalChristensen, H., Brown, J. K., and Ridout, C. J. 2008. Genetics of avirulence genes in Blumeria graminis f.sp. hordei and physical mapping of AVRa22 and AVRa12. Fungal Genet. Biol. 45:243-252.

Spanu P. D., Abbott J. C., Amselem J., Burgis T. A., Soanes D. M., Stuber K., Ver Loren van Themaat E., Brown J. K., Butcher S. A., Gurr S. J., Lebrun M. H., Ridout C. J., Schulze-Lefert P., Talbot N. J., Ahmadinejad N., Ametz C., Barton G. R., Benjdia M., Bidzinski P., Bindschedler L. V., Both M., Brewer M. T., Cadle-Davidson L., Cadle-Davidson M. M., Collemare J., Cramer R., Frenkel O., Godfrey D., Harriman J., Hoede C., King B. C., Klages S., Kleemann J., Knoll D., Koti P. S., Kreplak J., Lopez-Ruiz F. J., Lu X., Maekawa T., Mahanil S., Micali C., Milgroom M. G., Montana G., Noir S., O’Connell R. J., Oberhaensli S., Parlange F., Pedersen C., Quesneville H., Reinhardt R., Rott M., Sacristan S., Schmidt S. M., Schon M., Skamnioti P., Sommer H., Stephens A., Takahara H., Thordal-Christensen H., Vigouroux M., Wessling R., Wicker T., and Panstruga R. 2010. Genome expansion and gene loss in powdery mildew fungi reveal tradeoffs in extreme parasitism. Science 330:1543-1546.

Torp, J., and Jørgensen, J. H. 1986. Modification of barley powdery mildew resistance gene Ml-a12 by induced mutation. Can. J. Genet. Cytol. 28:725-731
Torp, J., Jensen, H. P., Jørgensen, J. H., and Helms, J. 1978. Powdery mildew resistance genes in 106 Northwest European spring barley varieties. Pages 27-44 in: The Royal Veterinary and Agricultural University Yearbook 1978, eds. The Royal Veterinary and Agricultural University Yearbook, Copenhagen.

Wei, F., Gobelman-Werner, K., Morroll, S. M., Kurth, J., Mao, L., Wing, R., Leister, D., Schulze-Lefert, P., and Wise, R. P. 1999. The Mla (powdery mildew) resistance cluster is associated with three NBS-LRR gene families and suppressed recombination within a 240-kb DNA interval on chromosome 5S (1HS) of barley. Genetics 153:1929-1948.

Wise, R., and Ellingboe, A. H. 1983. Infection kinetics of Erysiphe graminis f. sp. hordei on barley with different alleles at the $\mathrm{Ml}$ - $a$ locus. Phytopathology 73:1220-1222.

Wolfinger, R. D., Gibson, G., Wolfinger, E. D., Bennett, L., Hamadeh, H., Bushel, P., Afshari, C., and Paules, R. S. 2001. Assessing gene significance from cDNA microarray expression data via mixed models. J. Comput. Biol. 8:625-637.

Zhang, M., Boter, M., Li, K., Kadota, Y., Panaretou, B., Prodromou, C. Shirasu, K., and Pearl, L. H. 2008. Structural and functional coupling of Hsp90- and Sgt1-centered multi-protein complexes. EMBO (Eur. Mol. Biol. Organ.) J. 27:2789-2798.

Zhou, F., Kurth, J., Wei, F., Elliott, C., Valé, G., Yahiaoui, N., Keller, B., Somerville, S., Wise, R., and Schulze-Lefert, P. 2001. Cell-autonomous expression of barley Mlal confers race-specific resistance to the powdery mildew fungus via a Rarl-independent signaling pathway. Plant Cell 13:337-350.

Zierold, U. W. E., Scholz, U. W. E., and Schweizer, P. 2005. Transcriptome analysis of mlo-mediated resistance in the epidermis of barley. Mol. Plant Pathol. 6:139-151.

\section{AUTHOR-RECOMMENDED INTERNET RESOURCE}

ArrayExpress database: www.ebi.ac.uk/arrayexpress

BluGen, the Blumeria Sequencing Project website: www.blugen.org

Iowa State University GeneChip Core database: www.biotech.iastate.edu/facilities/genechip/Genechip.htm

PLEXdb database: plexdb.org

United States Department of Agriculture National Plant Germplasm System website: www.ars-grin.gov/npgs 